Ambiente \& Água - An Interdisciplinary Journal of Applied Science
ISSN 1980-993X - doi:10.4136/1980-993X
www.ambi-agua.net
E-mail: ambi.agua@gmail.com

\title{
Physical and chemical attributes of soil on gully erosion in the Atlantic forest biome
}

\author{
ARTICLES doi:10.4136/ambi-agua.2459
}

Received: 24 Aug. 2019; Accepted: 26 Jan. 2020

\section{João Henrique Gaia Gomes ${ }^{1}$; ; Marcos Gervasio Pereira ${ }^{2 *}$; Márcio Rocha Francelino ${ }^{3}$; João Pedro Bessa Larangeira2 ${ }^{2}$}

\author{
${ }^{1}$ Instituto de Agronomia. Departamento de Solos. Programa de Pós-Graduação em Agronomia. Universidade \\ Federal Rural do Rio de Janeiro (UFRRJ), BR 465, km 7, CEP: 23897-000, Seropédica, RJ, Brazil. \\ E-mail: gaia.gomes.pgeaamb@gmail.com \\ ${ }^{2}$ Instituto de Agronomia. Departamento de Solos. Universidade Federal Rural do Rio de Janeiro (UFRRJ), \\ BR 465, km 7, CEP: 23897-000, Seropédica, RJ, Brazil. E-mail: jp.larangeira@ gmail.com \\ ${ }^{3}$ Departamento de Solos. Universidade Federal de Viçosa (UFV), Av. P H Rolfs, S/N, CEP: 36570-900, \\ Viçosa, MG, Brazil. E-mail: marcio.francelino@gmail.com \\ *Corresponding author. E-mail: mgervasiopereira01@gmail.com
}

\begin{abstract}
Soil is a fundamental natural resource for subsistence and development of humanity, exploited mainly for agriculture. Agricultural practices, though, are improperly performed, compromising edaphic conditions and favoring erosive processes, which mainly culminate in the loss of soil and nutrients. Water erosion represents the main form of soil degradation, given that the impact of raindrops on the soil results in the detachment of particles, a process favored by factors such as climate, relief, soil vegetation and use and occupation. The objective of the study was to classify four gullies based on their evolutionary turns and to judge the physicalchemical classifications of the soil at the internal and external faces of the gullies. The morphology of the gullies was classified by aerial images generated by drones. The gullies were mapped using Google Earth images from 2016. The qualitative assessment was performed using the digital field-elevation curvature (MDESC) model with field validation. Deformed samples were collected at depths of 0-10 and 10-20 cm, while non-deformed samples were collected at depths of $0.0-0.10 \mathrm{~cm}$ to evaluate their chemical and physical attributes. A nonparametric 5\% Kruskal-Wallis statistical analysis was performed on the resulting data. The chemical and physical attributes of the soil differed according to the evolutionary stage of the surfaces (internal and external) at depths of 0 to $10 \mathrm{~cm}$, while the faces showed differences in depth of 10 to $20 \mathrm{~cm}$.
\end{abstract}

Keywords: erosive process, geotechnologies, soil quality indicators.

\section{Atributos físicos e químicos em voçorocas no Bioma da floresta Atlântica}

\section{RESUMO}

O solo é um recurso natural fundamental para a subsistência e desenvolvimento da humanidade, sendo principalmente explorado pela agricultura, cujas práticas inadequadas comprometem as condições edáficas, favorecendo a ocorrência de processos erosivos, que 
culminam principalmente na perda de solo e nutrientes. A erosão hídrica atua como principal forma de degradação do solo, em que, a partir da ação do impacto da gota de chuva sobre o solo, ocorre o desprendimento de partículas que, associadas a fatores como clima, relevo, solo vegetação e uso e ocupação, favorecem esse processo $O$ objetivo do estudo foi classificar quatro voçorocas com base em seus estágios evolutivos e julgar as classificações físicoquímicas do solo nas faces internas e externas das voçorocas. A morfologia das voçorocas foi classificada por imagem aérea gerada por drone. As voçorocas foram mapeadas usando imagens do Google Earth a partir de 2016. A avaliação qualitativa foi realizada usando o modelo digital de curvatura de elevação de campo (MDSC) com validação de campo. Amostras deformadas foram coletadas nas profundidades de 0-10 e 10-20 cm, enquanto amostras não deformadas foram coletadas em profundidades de $0-10 \mathrm{~cm}$ para avaliar seus atributos químicos e físicos. De posse dos dados foi realizada análise estatística não paramétrica de Kruskal-Wallis a 5\%. Os atributos químicos e físicos do solo diferiram de acordo com o estágio evolutivo nas faces (interna e externa) em profundidades de 0 a $10 \mathrm{~cm}$, enquanto as faces mostraram diferenças em profundidade de 10 a $20 \mathrm{~cm}$.

Palavras-chave: geotecnologias, indicadores de qualidade do solo, processos erosivos.

\section{INTRODUCTION}

A lack of technical information related to agricultural expansion has led to various forms of environmental damage. Agricultural development continues to have numerous effects on natural ecosystems, as best practices for environment conservation are not widely implemented. Previous studies (Laurance et al., 2014) have shown that problems in agriculture can negatively affect human well-being and environmental conservation.

Humans have a large impact on the environment (Ferreira et al., 2016) by affecting soil occupation, use, and management. Inadequate agricultural practices can damage the physical and chemical attributes of soil, affect water dynamics, and have various other consequences. According to Santos et al. (2017), improper management can lead to soil sealing, which increases surface runoff and, consequently, mass runoff.

Water erosion is one effect of improper management and greatly contributes to soil degradation. Bogunovic et al. (2018) described erosion as one of the main precursors of soil degradation. Erosion typically begins as raindrops impacting the soil, causing aggregates to rupture into individualized particles, which are more easily carried along the landscape by surface and subsurface runoff.

Linear erosion refers to the beginning of the erosive process, which can become laminar and evolve into a gully. The different proportions, dimensions, vegetation cover, and water dynamics are used to classify the gullies according to their morphology and evolutionary stages as initial, juvenile, mature, or senile (Dobek et al., 2011).

Gullies, which are defined as a result of an erosive process that removes soil mass and nutrients in an advanced stage, are found throughout the Cachimbal River sub-basin, that comprises a large part of the territorial extension of the municipality of Pinheiral, in the state of Rio de Janeiro - Brazil, which is the area of study. According to studies carried out in the area (Menezes et al., 2010; Santos et al., 2017), the occurrence of gullies may be associated with different forms of soil usage, occupation, and management.

Hence, this study hypothesized that edaphic attributes present differentiated patterns according to the evolutionary stages and (inner and outer) surface of the gully. The present study therefore aims to classify and evaluate the gullies based on their evolutionary stage and the physical and chemical attributes of the soil in their inner and outer surfaces. 


\section{MATERIALS AND METHODS}

The study was carried out in the Cachimbal River sub-basin, which composes a large part of the municipality of Pinheiral, Rio de Janeiro - Brazil (Figure 1). This sub-basin is in the region of Médio Paraíba Fluminense and makes up the Paraíba do Sul River basin.

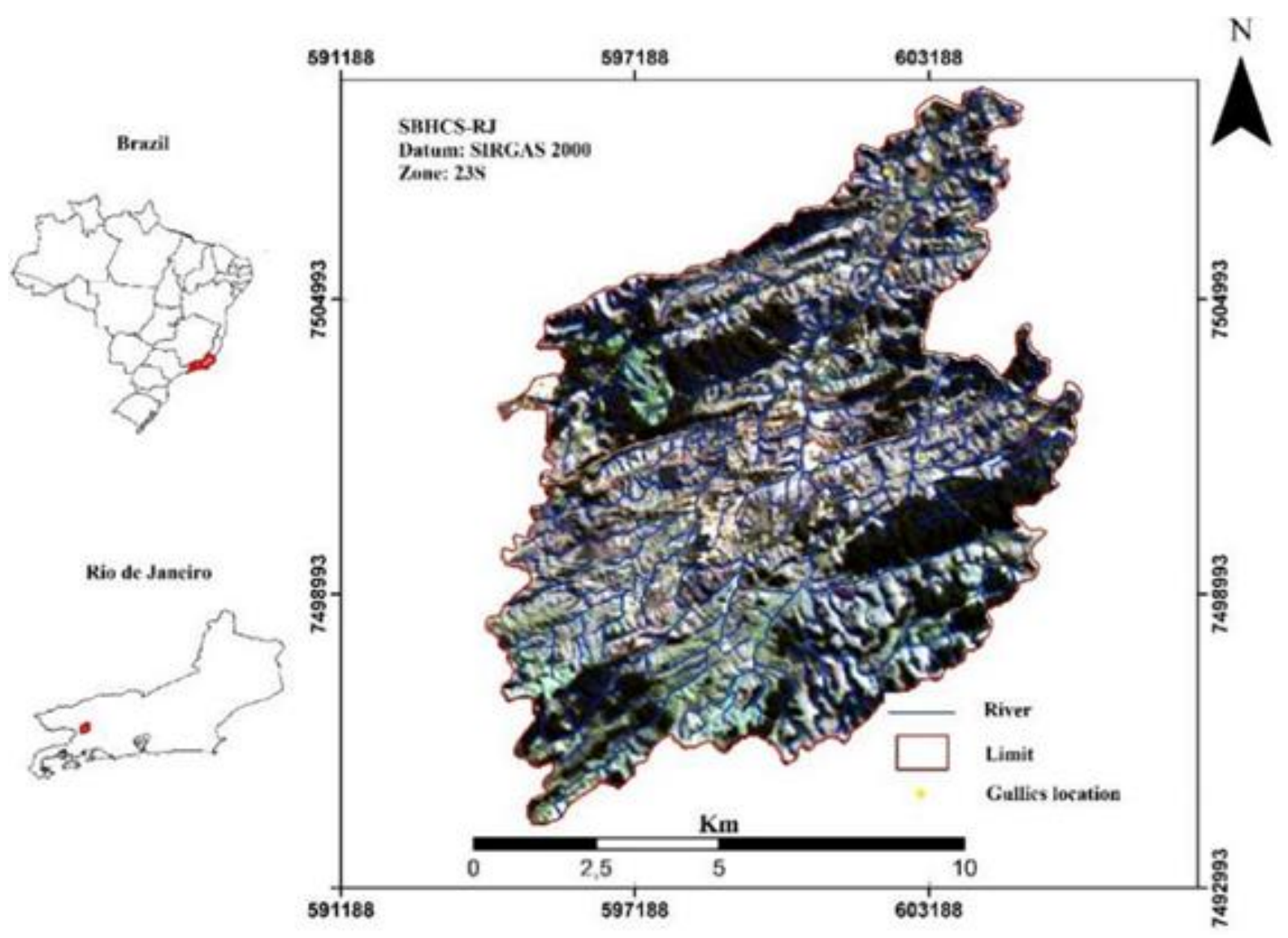

Figure 1. Sub-basin of Cachimbal Stream, Pinheiral - RJ.

The climate in the study area is classified as "temperate", with dry winters and rainy summers (Cwa), and rainy tropical climate with dry winters (Am), according to the Koppen climate classification (Alvares et al., 2014). The vegetative cover is currently comprised of implanted, spontaneous, and unmanaged pastures, which are degraded. During the colonial period in late 18th century, because of intense use and occupation, the region that once contained Floresta Estacional Semidecidual Submontana as its original vegetation underwent changes and this was replaced by coffee plantations. (Menezes et al., 2010).

The predominant soils in the Cachimbal Creek sub-basin are on the hillside, Ultisol (Argissolos Vermelho-Amarelos) and Inceptisol (Cambissolo Háplico), and summit and backslope of the hillside, Oxisol (Latossolos Vermelho-Amarelos) (Santos et al., 2017). According to Santos et al. (2016), the sub-basin's altitude varies from $360 \mathrm{~m}$ at the mouth of the Cachimbal Stream to $720 \mathrm{~m}$ in the Arrozal mountain range. Approximately $72 \%$ of the subbasin is comprised of hillsides with slopes, $22.3 \%$ of narrow cultivated plains, and $5.7 \%$ of hilltop areas.

The gullies were mapped using 2016 Google Earth images with a spatial resolution of 2.34 $\mathrm{m}$. In the images, four gullies were georeferenced to occur in convex pedoforms at different evolutionary stages, as in the Ribeirão Cachimbal sub-basin, where gullies generally have this topographic feature (pedoform) (Gaia-Gomes, 2017).

Qualitative classification was conducted using a digital model surface curvature (Figure 
2), which was generated using topographic charts of the municipalities of Volta Redonda (Sheet SF-23-ZAV-2) and Piraí (Sheet SF - 23-Z-VI-1), obtained from IBGE on the scale of 1:50,000, with a spatial resolution of $10 \mathrm{~m}$ on the scale of 1:100,000, via ArcGIS 10.5. The coordinates of the identified gullies were plotted using DMSC; after a convex surface emerged, and the results were validated through field analysis.

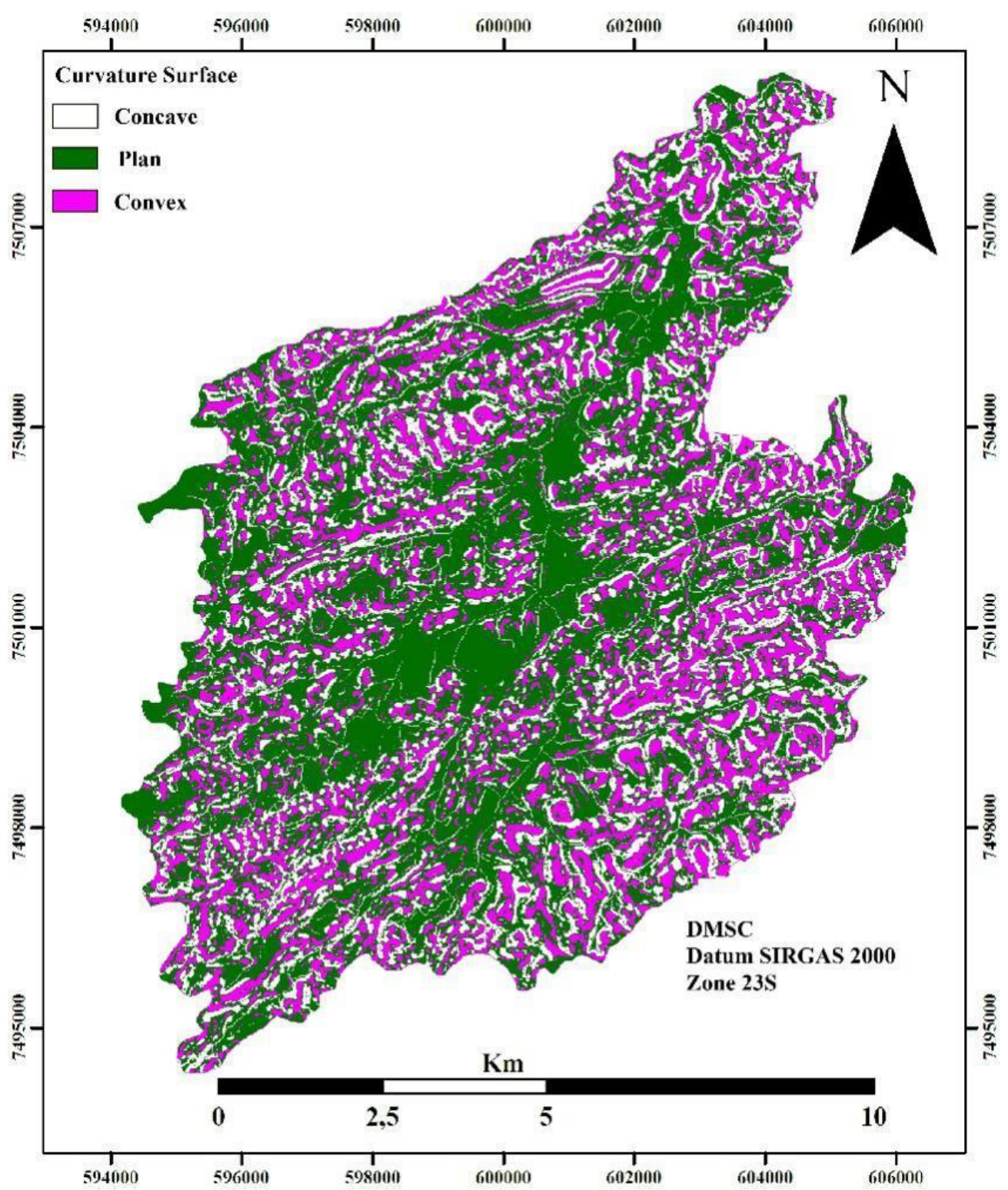

Figure 2. Digital Model of Sub-basin of Cachimbal Stream, Pinheiral - RJ.

A flight using the Drone model Phantom 4 was performed on an exposure strand with four gullies that emerged in a convex pedoform (Figure 3). In such pedoform, the gullies were classified according to their morphology as initial, juvenile, mature, or senile (Dobek et al., 2011; Cherobin, 2012).

The selected gullies were divided according to their inner and outer surfaces. Deformed samples were collected at depths of $0-10$ and 10-20 cm and non-deformed samples were collected at depths of $0-10 \mathrm{~cm}$ to evaluate their chemical and physical attributes. In the gully classified as initial, 10 deformed and 10 non-deformed samples were collected; in the juvenile gully, 12 deformed and 12 non-deformed samples were collected; in the mature gully, 16 deformed and 16 non-deformed samples were collected; and in the senile, 18 deformed and 18 
non-deformed samples were collected at both depths. The Kopeck ring was used to collect the non-deformed samples.

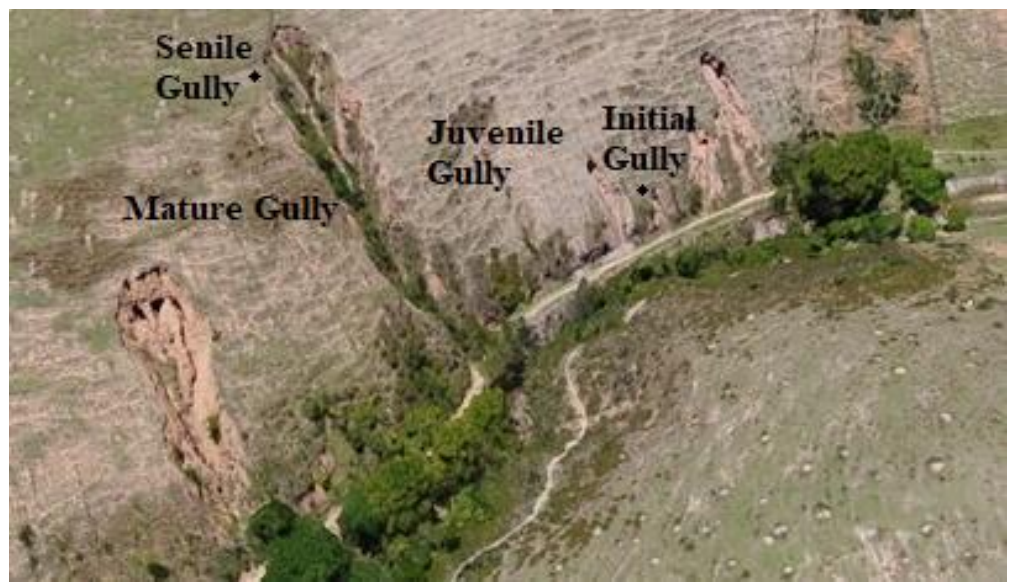

Figure 3. Gullies in different evolutionary stages in the selected exhibition area.

After collection, the deformed samples were dried, discharged, and passed through a 2$\mathrm{mm}$ sieve to obtain an air-dried thin earth sample according to the method reported by Santos et al. (2015).

The values of $\mathrm{pH}$ in water and $\mathrm{Ca}^{2+}, \mathrm{Mg}^{2+}, \mathrm{Al}^{3+}, \mathrm{K}^{+}, \mathrm{Na}^{+}, \mathrm{P}, \mathrm{H}+\mathrm{Al}$ contents were determined as described by Teixeira et al. (2017). Total organic carbon (TOC) contents were quantified according to Yeomans and Bremner (1988). S values (sum of the $\mathrm{Ca}^{+2}, \mathrm{Mg}^{+2}, \mathrm{~K}^{+}$, and $\mathrm{Na}^{+}$contents), $\mathrm{T}$ values were calculated, and $\mathrm{V} \%$ was estimated according to Teixeira $e t$ al. (2017).

For physical attributes, bulk density (Bd), particle density $(\mathrm{Pd})$ and total porosity volume (TPV) were calculated as described by Teixeira et al. (2017).

Particle size analysis was carried out to quantify the following soil fractions: total sand ( $\mathrm{g}$ $\left.\mathrm{kg}^{-1}\right)$, coarse sand $\left(\mathrm{g} \mathrm{kg}^{-1}\right)$, fine sand $\left(\mathrm{g} \mathrm{kg}^{-1}\right)$, total clay $\left(\mathrm{g} \mathrm{kg}^{-1}\right)$, natural clay $\left(\mathrm{g} \mathrm{kg}^{-1}\right)$, and silt $(\mathrm{g}$ $\mathrm{kg}^{-1}$ ) (Teixeira et al., 2017). Based on the results of granulometric analysis, the degree of flocculation (DF\%) were calculated as described by Teixeira et al. (2017).

After identifying and classifying the evolutionary stages of the gullies, the possible differences between the evolutionary stages and faces of the gullies were evaluated by the Kruskal-Wallis test, at a 5\% significance level.

To evaluate the correlations between variables in the gullies, the Pearson correlation test was performed. A p-value $<0.05$ was considered to indicate a statistically significant difference. The XLSTAT software was used for the analysis.

Principal component analysis was carried out using the XLSTAT program to determine which chemical and physical variables could be used to indicate similarity or dissimilarity among the evolutionary stages and faces of the gullies.

\section{RESULTS AND DISCUSSION}

The curvature surface, with the flat category represented the largest percentage of the subbasin area (59.3\%). The lowest area value was observed in the concave category (19.1\%). The convex category represented $(21.6 \%)$ of the total area.

According to Arthur et al. (2014), concave, flat, and convex surfaces influence sediment production and intensity and direction of water flow in the soil profile. According to Aumond et al. (2014), concave surfaces are characterized by microclimatic, topographic, and solar radiation conditions directed towards the interior, promoting greater concentration of matter 
and energy. Additionally, water, sediment, mineral, and organic matter accumulation can occur in this pedoform.

The convex pedoform showed different water dynamics in which the surface runoff of water and sediments was associated with the external and internal flow of matter and energy, leading to energy dissipation and losses caused by erosion and leaching (Aumond et al., 2014). Table 1.

The chemical and physical attributes of soil at a depth of $0-10 \mathrm{~cm}$ are presented in

Regarding the granulometric fractions for natural clay, differences were observed between the juvenile and mature stages and between the juvenile and senile stages on the outer surface. Among these, differences were observed only in the juvenile stage, with the highest values occurring for the inner surface. This pattern may be associated with the stabilization process that tends to occur between the mature and senile stages, in which particle drifts occur more slowly, in contrast to those in the juvenile stage in which more intense erosion is observed and causes greater removal of sediments.

For the total clay fraction, differences between the initial and mature, initial and senile, juvenile and mature, and juvenile and senile stages on the outer face were observed, with the highest values quantified for the outer face of mature and senile gullies. Differences were observed between the initial stages of the erosive process (initial and juvenile) and transition/stabilization process (mature and senile). Fractions of smaller granulometry, such as clay, may develop with lower intensity in the transition/stabilization processes, as their surface runoff occurs to a lesser extent because of the presence of vegetation cover and colonization of plant species from mass flow.

The highest values of the flocculation degree were observed for the outer face of the juvenile gully, showing large differences between the initial and juvenile and between the juvenile and senile stages. The internal and external faces of the initial and senile stages showed significant differences. Flocculation degree is inversely proportional to the natural clay content, and soils with lower values are more vulnerable to water erosion (Lima et al., 2013). The observed pattern may be related to the removal of naturally dispersed clay particles via the erosive process, in which only flocculated particles remain, increasing the degree of flocculation. According to Ayer et al. (2015), lower levels of flocculation occur when soil conservation methods are not implemented and because of inadequate management, favoring the destruction of aggregates and reduction of soil permeability.

For the total sand fraction, the highest values were observed for the inner face of the initial gully. The same pattern was observed for coarse sand. The gullies classified as initial and senile presented differences between themselves and for the two physical attributes mentioned above on the inner face. Differences were observed on the inner face of gullies in the initial and mature stage and in the juvenile and mature stages, which did not corroborate the results for the coarse sand fraction for which only a difference between the juvenile and mature stages was found. On the faces, differences were only observed for the mature gully. The observed pattern may be associated with surface runoff, which tends to occur with greater intensity in the initial and juvenile stage, carrying particles from the outer to the inner face, which remain stationary inside the gully until water dynamics modify this pattern.

The lowest values of the fine sand fraction were observed for the inner face of the mature gully. Differences were found for both faces between the initial and mature stages and on the external face between juvenile and mature stages as well as juvenile and senile stages. Lower values of fine sand are also related to surface runoff. Granulometry fractions with smaller diameters require less kinetic energy to be transported. This attribute was weak in the gully classified as mature, but strengthened in the senile stage, indicating that a transitional stage occurred followed by stabilization (Table 1). 
Table 1. Averages of the chemical and physical attributes of the soil of the initial, juvenile, mature and senile gullies at 0-10 cm depth on the inner (I) and outer (E) faces.

\begin{tabular}{|c|c|c|c|c|c|c|}
\hline \multirow{3}{*}{ Stages } & \multicolumn{2}{|c|}{$\mathrm{pH}$} & \multicolumn{2}{|c|}{$\mathrm{Ca}$} & \multicolumn{2}{|c|}{$\mathrm{Mg}^{+2}$} \\
\hline & \multicolumn{6}{|c|}{$\left(\mathrm{cmol}_{\mathrm{c}} \mathrm{kg}^{-1}\right)$} \\
\hline & I & $\mathbf{E}$ & I & $\mathbf{E}$ & I & $\mathbf{E}$ \\
\hline Initial & $5.01 \mathrm{aA}$ & $4.98 \mathrm{aA}$ & $0.99 \mathrm{cA}$ & $0.97 \mathrm{bB}$ & $1.15 \mathrm{aA}$ & $1.18 \mathrm{aA}$ \\
\hline Juvenile & $4.94 \mathrm{aA}$ & $4.76 \mathrm{bA}$ & $1.16 \mathrm{bA}$ & 1.12abA & 1.11abA & $1.16 \mathrm{aA}$ \\
\hline Mature & $4.89 \mathrm{aA}$ & 4.84abA & $1.21 \mathrm{abA}$ & $0.96 \mathrm{bA}$ & $0.97 \mathrm{bcB}$ & $1.03 \mathrm{aA}$ \\
\hline Senile & $4.99 \mathrm{aA}$ & $4.98 \mathrm{aA}$ & $1.26 \mathrm{aA}$ & $1.28 \mathrm{aA}$ & $0.87 \mathrm{cA}$ & $0.86 \mathrm{bB}$ \\
\hline \multirow{3}{*}{ Stages } & \multicolumn{2}{|c|}{$\mathrm{Al}^{3+}$} & \multicolumn{2}{|c|}{$\mathrm{H}+\mathrm{Al}$} & \multicolumn{2}{|c|}{$\mathrm{Na}^{+}$} \\
\hline & \multicolumn{6}{|c|}{$\left(\mathrm{cmol}_{\mathrm{c}} \mathrm{kg}^{-1}\right)$} \\
\hline & I & $\mathbf{E}$ & I & $\mathbf{E}$ & I & $\mathbf{E}$ \\
\hline Initial & $0.81 \mathrm{aB}$ & $0.99 \mathrm{bA}$ & $1.75 \mathrm{bA}$ & $2.42 \mathrm{abA}$ & $0.010 \mathrm{aA}$ & $0.010 \mathrm{aA}$ \\
\hline Juvenile & $0.97 \mathrm{aA}$ & $1.24 \mathrm{aA}$ & 2.13abA & $2.12 \mathrm{aA}$ & $0.010 \mathrm{aA}$ & $0.010 \mathrm{aA}$ \\
\hline Mature & $1.08 \mathrm{aA}$ & 1.12abA & $1.54 \mathrm{bA}$ & $2.44 \mathrm{bA}$ & $0.010 \mathrm{aA}$ & $0.010 \mathrm{aA}$ \\
\hline \multirow[t]{2}{*}{ Senile } & $0.98 \mathrm{aA}$ & $0.99 \mathrm{bB}$ & $2.47 \mathrm{aA}$ & $2.92 \mathrm{aA}$ & $0.010 \mathrm{aA}$ & $0.010 \mathrm{aA}$ \\
\hline & \multicolumn{2}{|c|}{$\mathrm{K}^{+}$} & \multicolumn{2}{|c|}{ TOC } & \multicolumn{2}{|c|}{ S Value } \\
\hline \multirow[t]{2}{*}{ Stages } & \multicolumn{2}{|c|}{$\left(\mathrm{cmol}_{\mathrm{c}} \mathrm{kg}^{-1}\right)$} & \multicolumn{2}{|c|}{$\left(\mathrm{g} \mathrm{kg}^{-1}\right)$} & \multicolumn{2}{|c|}{$\left(\mathrm{cmol}_{\mathrm{c}} \mathrm{kg}^{-1}\right)$} \\
\hline & I & $\mathbf{E}$ & I & $\mathbf{E}$ & I & $\mathbf{E}$ \\
\hline Initial & $0.010 \mathrm{aA}$ & $0.012 \mathrm{aA}$ & $6.57 \mathrm{bB}$ & $10.38 \mathrm{aA}$ & $2.20 \mathrm{aA}$ & $2.14 \mathrm{abA}$ \\
\hline Juvenile & $0.010 \mathrm{abA}$ & $0.011 \mathrm{aA}$ & $12.51 \mathrm{aA}$ & $13.75 \mathrm{aA}$ & $2.30 \mathrm{aA}$ & $2.30 \mathrm{aA}$ \\
\hline Mature & $0.009 \mathrm{bcA}$ & $0.008 \mathrm{aB}$ & $10.65 \mathrm{abA}$ & $13.12 \mathrm{aA}$ & $2.20 \mathrm{aA}$ & $2.17 \mathrm{bA}$ \\
\hline Senile & $0.008 \mathrm{cB}$ & $0.007 \mathrm{bA}$ & $13.42 \mathrm{aA}$ & $14.20 \mathrm{aA}$ & $2.18 \mathrm{aA}$ & $2.16 \mathrm{abA}$ \\
\hline \multirow{3}{*}{ Stages } & \multicolumn{2}{|c|}{$\mathrm{T}$ Value } & \multicolumn{2}{|c|}{$\mathrm{V}$} & & \\
\hline & & & & & & \\
\hline & I & $\mathbf{E}$ & I & $\mathbf{E}$ & I & $\mathbf{E}$ \\
\hline Initial & $4.50 \mathrm{abA}$ & $4.77 \mathrm{bcA}$ & $56.00 \mathrm{aA}$ & $45.00 \mathrm{aA}$ & $263.00 \mathrm{aA}$ & $252.00 \mathrm{cB}$ \\
\hline Juvenile & 4.430abA & $5.32 \mathrm{aA}$ & $53.50 \mathrm{abA}$ & $43.40 \mathrm{aA}$ & $301.00 \mathrm{aA}$ & $284.70 \mathrm{bcB}$ \\
\hline Mature & $4.34 \mathrm{bA}$ & $4.47 \mathrm{cA}$ & $61.63 \mathrm{aA}$ & $45.70 \mathrm{aA}$ & $336.70 \mathrm{aA}$ & $372.31 \mathrm{aA}$ \\
\hline Senile & $4.00 \mathrm{aA}$ & $5.08 \mathrm{abA}$ & $47.35 \mathrm{bA}$ & $45.00 \mathrm{aA}$ & $263.25 \mathrm{aA}$ & $334.56 \mathrm{abA}$ \\
\hline & & & & & & \\
\hline Stages & & & & & & \\
\hline & I & $\mathbf{E}$ & I & $\mathbf{E}$ & I & $\mathbf{E}$ \\
\hline Initial & $101.90 \mathrm{aA}$ & 75.30abA & $61.71 \mathrm{aB}$ & $69.10 \mathrm{bA}$ & $576.80 \mathrm{aA}$ & $532.70 \mathrm{abA}$ \\
\hline Juvenile & $131.65 \mathrm{aA}$ & $37.00 \mathrm{bB}$ & $51.81 \mathrm{aA}$ & 86.38aA & $516.90 \mathrm{abA}$ & $540.00 \mathrm{aA}$ \\
\hline Mature & $124.81 \mathrm{aA}$ & $97.20 \mathrm{aA}$ & $60.36 \mathrm{aA}$ & 73.61abA & 477.31abA & $421.13 \mathrm{cB}$ \\
\hline Senile & $101.40 \mathrm{aA}$ & $104.25 \mathrm{aA}$ & $56.40 \mathrm{aB}$ & $68.68 \mathrm{bA}$ & $425.65 \mathrm{bA}$ & $428.38 \mathrm{bcA}$ \\
\hline & & & & & & \\
\hline Stages & & & & & & \\
\hline & I & $\mathbf{E}$ & I & $\mathbf{E}$ & I & $\mathbf{E}$ \\
\hline Initial & $129.20 \mathrm{aA}$ & $133.80 \mathrm{abA}$ & $447.20 \mathrm{aA}$ & $398.90 \mathrm{abA}$ & $160.20 \mathrm{bB}$ & $214.50 \mathrm{aA}$ \\
\hline Juvenile & $131.82 \mathrm{abA}$ & $138.83 \mathrm{aA}$ & $385.10 \mathrm{abA}$ & $403.70 \mathrm{aA}$ & $181.20 \mathrm{bA}$ & $175.30 \mathrm{aB}$ \\
\hline Mature & $96.87 \mathrm{bA}$ & $88.75 \mathrm{cB}$ & $380.40 \mathrm{abA}$ & $332.40 \mathrm{bA}$ & $186.10 \mathrm{bB}$ & $206.60 \mathrm{aA}$ \\
\hline Senile & 103.50abA & $100.31 \mathrm{bcB}$ & $322.20 \mathrm{bA}$ & $337.30 \mathrm{abA}$ & $311.10 \mathrm{aA}$ & $237.10 \mathrm{aA}$ \\
\hline & & & & & & \\
\hline Stages & & & & & & \\
\hline & I & $\mathbf{E}$ & I & $\mathbf{E}$ & I & $\mathbf{E}$ \\
\hline Initial & $1.12 \mathrm{abA}$ & $1.47 \mathrm{aA}$ & $2.48 \mathrm{aA}$ & $2.37 \mathrm{aA}$ & $54.60 \mathrm{aA}$ & $37.70 \mathrm{aA}$ \\
\hline Juvenile & $1.10 \mathrm{bB}$ & $1.42 \mathrm{aA}$ & $2.39 \mathrm{aA}$ & $2.36 \mathrm{aA}$ & $55.72 \mathrm{aA}$ & $39.60 \mathrm{aA}$ \\
\hline Mature & $1.14 \mathrm{bB}$ & $1.44 \mathrm{aA}$ & 2.35abA & $2.26 \mathrm{aA}$ & $51.56 \mathrm{aA}$ & 35.88aA \\
\hline Senile & $1.28 \mathrm{aA}$ & $1.43 \mathrm{aA}$ & $2.28 \mathrm{bB}$ & $2.33 \mathrm{aA}$ & $43.80 \mathrm{bA}$ & $38.44 \mathrm{aB}$ \\
\hline
\end{tabular}

Equal lowercase letters in the column concern evolutionary stages and equal uppercase letters in the row are inner and outer surfaces, and do not differ by the Kruskal-Wallis test at 5\% significance. I: inner face of the gullies; E: outer face of the gullies; TOC: Total Organic Carbon; Bd: bulk density; Pd: Particles density; TPV: Total Porosity Volume.

For the silt fraction, the highest value was observed for the inner face of the senile gully, showing a difference between the initial and senile, juvenile and senile, and mature and senile 
stages. Between faces, differences were observed for the initial, juvenile and mature stages. Like the fine sand fraction, silt is one of the fractions most susceptible to disaggregation and transport (Albuquerque et al., 2013).

Analysis of bulk density (Bd) values revealed higher values for the outer face of the gullies. Differences were detected between the juvenile and senile stages and between mature and senile stages in the inner face. A difference was also observed between the faces of the gullies in the juvenile and mature stages. The soil structure influences its $\mathrm{Bd}$, making it possible to predict the impacts of erosive processes. In general, higher values of $\mathrm{Bd}$ are related to a high degree of soil compaction. Compaction is directly proportional to $\mathrm{Bd}$, which results in lower porosity, reducing the internal flow of water and favoring superficial runoff.

The area has a long history of use and occupation for coffee cultivation and pasture, possibly contributing to the increased Bd which, according to Sousa Neto et al. (2014), is normally higher in managed areas possibly because of soil compaction. Compared to other gully types, the senile gully has larger dimensions and a greater depth, resulting in higher Bs values inside.

For the particle density (Pd), differences were observed between the initial and senile and between the juvenile and senile stages for the inner face, as well as between faces in the senile stage. Schjønning et al. (2017) predicted soil particle density from organic matter and clay contents and found that a higher organic matter content was associated with lower Pd values.

The highest total porosity volume (TPV) values were found for the inner face of the gullies. Deng et al. (2016) observed a similar pattern when studying the effect of land use on the physical and chemical properties of soils and erodibility in gully sediments in the municipality of Anxi, China. Differences were observed in the internal face between the initial and senile, juvenile and senile, and mature and senile gullies. The faces differed in the gullies classified as senile, where a higher value was observed for the inner face. Mass runoff originating from the erosive process culminates in soil disintegration, altering the soil porosity distribution that initiates restructuring on the inner side of the gully in the senile stage, since it is under spontaneous and natural regeneration.

The highest $\mathrm{pH}$ values were found for the inner side of the gullies, while the highest values were found in the initial gully, with a difference between the initial and juvenile as well as between juvenile and senile stages. For exchangeable $\mathrm{Al}^{3+}$ values, the same pattern was observed as for $\mathrm{pH}$ between stages, but with smaller values for the inner face. This pattern was also observed in the faces of the initial and senile gullies, which also showed differences.

The values of TOC followed the same pattern as $\mathrm{H}+\mathrm{Al}$, with higher values of TOC observed for the senile stage and on the outer face, which may be associated with the addition of organic matter from the vegetation at this evolutionary stage. For this attribute, a difference was observed between the initial and juvenile as well as between the initial and senile stages on the inner face. For $\mathrm{H}+\mathrm{Al}$, there were differences between the initial and senile stages as well as between the mature and senile stages on the inner face, and between the juvenile and mature and the mature and senile stages on the outer face.

For $\mathrm{Ca}^{2+}$, the highest values were observed for the gully going through the senile stage, showing the same pattern as TOC contents, which may be associated with the decomposition of vegetable material originating from the vegetation present on the surface of this gully. The $\mathrm{Ca}^{2+}$ values differed between the initial and senile stages and between the juvenile and senile stages on the inner face, as well as between the initial and senile stages and between the mature and senile stages on the outer face. A difference in the faces was detected in the initial stage.

For the $\mathrm{Mg}^{2+}$ and $\mathrm{K}^{+}$values, the largest values were observed in the outer face of the gullies, with the highest ones in the initial stage. When this attribute was compared, according to the evolutionary stage of the gullies, a difference was observed between the initial and mature 
stages, initial and senile stages, and juvenile and senile stages on the inner face and between the initial and senile stages, juvenile and senile stages, and mature and senile stages on the outer face. The faces differed between the mature and senile stages. The observed pattern may be related to the absorption of these nutrients by the plants found on the inner face and edges of the gully in the senile stage.

Lower $\mathrm{S}$ values were observed in the senile stage, while higher values were observed in the outer face. A difference between the juvenile and mature stages was only found on the outer face, which may be related to leaching losses.

The $\mathrm{T}$ and $\mathrm{V}(\%)$ values differed between the mature and senile stages on the inner face. For the $\mathrm{T}$ value in the outer face, differences between the initial and juvenile stages and between the juvenile and mature stages were observed. The highest value was observed in the outer face of the juvenile gully, differing from the one observed in V (\%), in which the highest value was found in the outer face of the gully in mature stage. These results can be attributed to the decomposition and mineralization processes that develop at different intensities because of the characteristics of each stage, water dynamics, surface runoff, and availability of organic matter (Machado et al., 2010; Gomide et al., 2011).

No differences were observed between the evolutionary stages and faces in $\mathrm{Na}^{+}$contents. Figure 4 shows the results of the analysis of the main components (PCA) and Table 2 shows the values of the correlations between chemical and physical attributes of the soil and axes at a depth of $0-10 \mathrm{~cm}$, showing a significant correlation at $5 \%$ in the Pearson test. The soil variables $\mathrm{pH}, \mathrm{Ca}^{2+}, \mathrm{Al}^{3+}, \mathrm{Na}^{+}, \mathrm{S}$ value, total clay, and natural clay at $0-10 \mathrm{~cm}$ depth were not significantly correlated at a cut-off of $5 \%$ in the Pearson test.

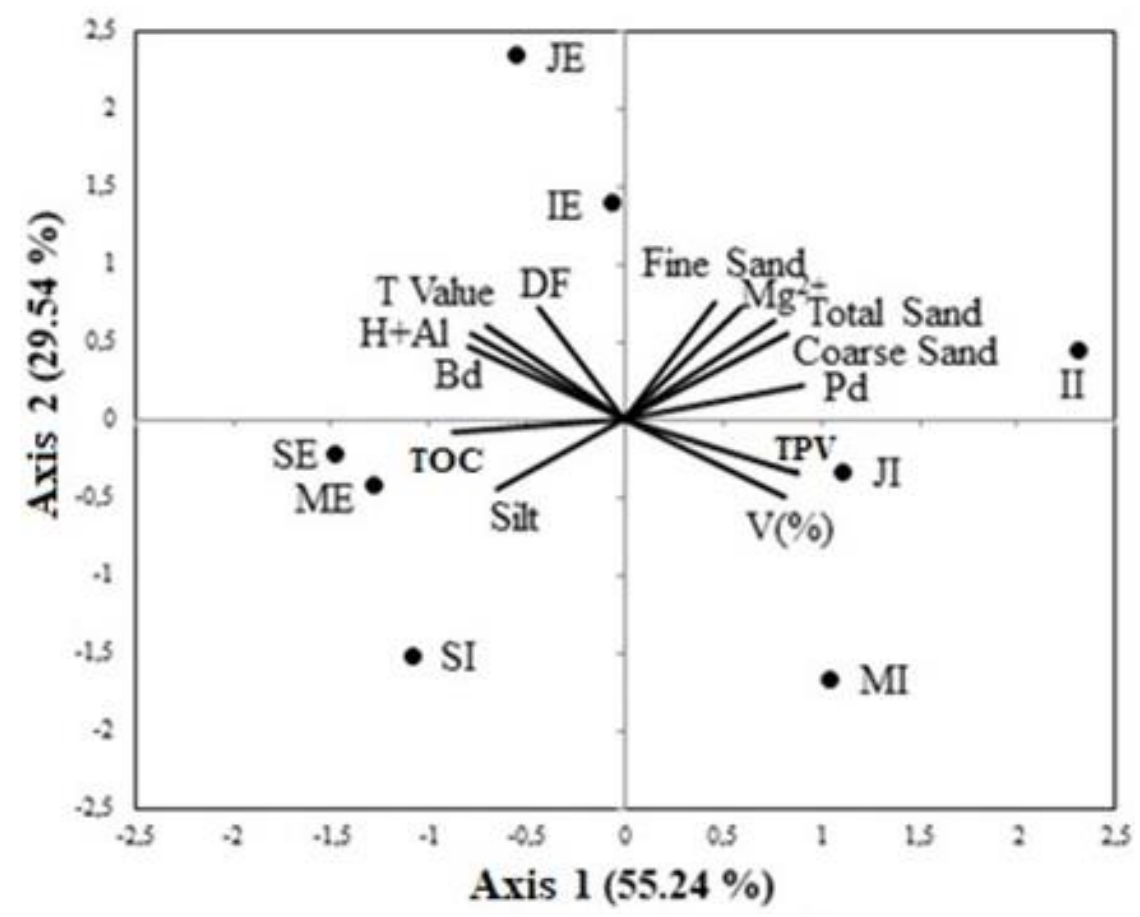

Figure 4. PCA for chemical and physical variables of the soil in the four evolutionary stages and internal and external faces of the gullies in depth of $0-10 \mathrm{~cm}$.

The PCA analysis showed that, for the relationship between the 1 and 2 axes, there was a separation in the chemical and physical attributes of the soil among the evolutionary stages and on the inner and outer faces (II: inner face of the initial stage, IE: outer face of the initial stage, JI: inner face of the juvenile stage, JE: outer face of the initial stage; MI: inner face of the mature stage, ME: outer face of the mature stage, SI: inner face of the senile stage, SE: outer face of 
the senile stage). The sum of the two axes explained the value of $84.78 \%$, with axis 1 explaining $55.24 \%$ and axis 2 explaining $29.54 \%$.

Table 2. Values of the correlations between the soil's chemical and physical attributes of the soil and the axes in depth of $0-10 \mathrm{~cm}$ in the analyzed stages.

\begin{tabular}{cccccc}
\hline \multirow{2}{*}{ Axis } & \multicolumn{6}{c}{ Chemical Attributes } \\
\cline { 2 - 6 } & $\mathbf{M g}^{2+}$ & H+Al & TOC & T Value & V (\%) \\
\hline $\mathbf{1}$ & 0.58 & -0.79 & -0.87 & -0.70 & 0.82 \\
$\mathbf{2}$ & 0.72 & 0.55 & -0.09 & 0.60 & -0.50 \\
\hline \multirow{5}{*}{ Axis } & \multicolumn{7}{c}{ Physical Attributes } \\
\cline { 2 - 6 } & Total Sand & Fine Sand & Coarse Sand & DF & Silt \\
\hline $\mathbf{1}$ & 0.76 & 0.45 & 0.82 & -0.44 & -0.65 \\
$\mathbf{2}$ & 0.64 & 0.76 & 0.55 & -0.72 & -0.45 \\
\hline Axis & Bd & Pd & TPV & & \\
\hline $\mathbf{1}$ & -0.80 & 0.90 & 0.87 & & \\
$\mathbf{2}$ & 0.46 & 0.22 & -0.35 & \\
\hline
\end{tabular}

For stage II, the variables for coarse sand $(r=0.82)$, total sand $(r=0.76)$, and $\mathrm{Pd}(\mathrm{r}=0.90)$ were associated, correlating positively with axis 1 , and variables $\mathrm{Mg}(\mathrm{r}=0.72)$ and fine sand $(\mathrm{r}$ $=0.76)$ correlated positively with axis 2 . Regarding JI and MI, the most associated variables were TPV $(r=0.87)$ and V\% $(r=0.82)$, which showed a positive correlation. The variables most associated with IE and JE, DF $(r=0.72)$ correlated positively with axis 2 and $\mathrm{Bd}(\mathrm{r}=0.80)$ showing a positive correlation, while $\mathrm{H}+\mathrm{Al}(\mathrm{r}=0.79)$ and the $\mathrm{T}$ value $(\mathrm{r}=-0.70)$ showed a negative correlation with axis 1 . For the ME, SE, and SI stages, the most associated variables were TOC $(r=-0.87)$ and silt $(r=-0.65)$, which showed a negative correlation with axis 1 .

Analysis of axis 1 verified that although there was a division among stages, the internal face of the gully classified as senile (SI) presented a different distribution pattern than the other stages. The interior of the gullies is a modified environment, in which the erosive process of mass drainage has already occurred and may present changes compared to the outer face.

Arthur et al. (2014) and Santos et al. (2016) found that small variations in relief forms influence the variability in edaphic factors. The pattern observed in SI may be associated with spontaneous natural regeneration that occurs in the interior, which is the only parameter showing this pattern. Regeneration tends to improve soil quality by altering fertility, aeration, aggregation, water infiltration, and biological activity.

The chemical and physical attributes of the soil at 10-20 cm depth are presented in Table 3.

For the chemical attributes $\mathrm{Al}^{3+}, \mathrm{Na}^{+}, \mathrm{K}^{+}$, natural clay, flocculation degree, total sand, and fine sand, no differences were observed among evolutionary stages or between the inner and outer faces of the gullies. The lowest $\mathrm{pH}$ values were observed for the outer face, with a difference between the initial and juvenile stages, juvenile and senile stages, and mature and senile stages. For $\mathrm{Ca}^{2+}$ levels, differences between the initial and juvenile stages, initial and mature stages, and initial and senile stages were observed. Among the faces of the gullies, a difference was observed in the mature gully, in which the highest value was observed in the inner face. The largest $\mathrm{Mg}^{2+}$ values were found for the outer face. When evolutionary stages were compared, only differences between the initial and mature stages were observed for initial and senile on both faces, and the highest values for $\mathrm{Mg}^{2+}$ were found in the initial stage. 
Table 3. Averages of the chemical and physical attributes of the soil initial, juvenile, mature and senile gullies at 0-20 cm depth on the inner (I) and outer (E) faces.

\begin{tabular}{|c|c|c|c|c|c|c|}
\hline \multirow{3}{*}{ Stages } & \multicolumn{2}{|c|}{$\mathrm{pH}$} & \multicolumn{2}{|c|}{$\mathrm{Ca}^{2+}$} & \multicolumn{2}{|c|}{$\mathrm{Mg}^{2+}$} \\
\hline & \multicolumn{6}{|c|}{$\left(\mathrm{cmolc} \mathrm{kg}^{-1}\right)$} \\
\hline & I & $\mathbf{E}$ & I & $\mathbf{E}$ & I & $\mathbf{E}$ \\
\hline Initial & $4.93 \mathrm{aA}$ & 4.79abA & $0.85 \mathrm{bA}$ & $0.81 \mathrm{abA}$ & $1.09 \mathrm{aA}$ & $1.13 \mathrm{aA}$ \\
\hline Juvenile & 4.96aA & $4.65 \mathrm{cB}$ & $1.02 \mathrm{aA}$ & $0.91 \mathrm{abA}$ & $0.92 \mathrm{abA}$ & $0.98 \mathrm{abA}$ \\
\hline Mature & $4.95 \mathrm{aA}$ & $4.73 b c B$ & $1.08 \mathrm{aA}$ & $0.76 \mathrm{bB}$ & $0.84 \mathrm{bA}$ & $0.84 \mathrm{bA}$ \\
\hline Senile & $4.92 \mathrm{aA}$ & $4.85 \mathrm{aA}$ & $1.05 \mathrm{aA}$ & $0.96 \mathrm{aA}$ & $0.93 \mathrm{bA}$ & $0.95 \mathrm{bA}$ \\
\hline \multirow{3}{*}{ Stages } & \multicolumn{2}{|c|}{$\mathrm{Al}^{3+}$} & \multicolumn{2}{|c|}{$\mathrm{H}+\mathrm{Al}$} & \multicolumn{2}{|c|}{$\mathrm{Na}^{+}$} \\
\hline & \multicolumn{6}{|c|}{$\left(\mathrm{cmolc} \mathrm{kg}^{-1}\right)$} \\
\hline & I & $\mathbf{E}$ & I & $\mathbf{E}$ & I & $\mathbf{E}$ \\
\hline Initial & $0.96 \mathrm{aA}$ & $1.35 \mathrm{abA}$ & 1.99abA & $2.64 \mathrm{abA}$ & $0.010 \mathrm{aA}$ & $0.010 \mathrm{aA}$ \\
\hline Juvenile & $0.98 \mathrm{aA}$ & $1.46 \mathrm{aA}$ & $2.16 \mathrm{aA}$ & $3.02 \mathrm{aA}$ & $0.010 \mathrm{aA}$ & $0.010 \mathrm{aA}$ \\
\hline Mature & $0.87 \mathrm{aA}$ & $1.23 \mathrm{abA}$ & $1.13 \mathrm{bA}$ & $2.34 \mathrm{bA}$ & $0.010 \mathrm{aA}$ & $0.010 \mathrm{aA}$ \\
\hline Senile & $1.10 \mathrm{aA}$ & $1.31 \mathrm{aA}$ & $2.50 \mathrm{aA}$ & $3.10 \mathrm{aA}$ & $0.010 \mathrm{aA}$ & $0.010 \mathrm{aA}$ \\
\hline \multirow{3}{*}{ Stages } & \multicolumn{2}{|c|}{$\mathrm{K}^{+}$} & \multicolumn{2}{|c|}{ TOC } & \multicolumn{2}{|c|}{ S Value } \\
\hline & \multicolumn{2}{|c|}{$\left(\mathrm{cmol}_{\mathrm{c}} \mathrm{kg}^{-1}\right)$} & \multicolumn{2}{|c|}{$\left(\mathrm{g} \mathrm{kg}^{-1}\right)$} & \multicolumn{2}{|c|}{$\left(\mathrm{cmol}_{\mathrm{c}} \mathrm{kg}^{-1}\right)$} \\
\hline & I & $\mathbf{E}$ & I & $\mathbf{E}$ & I & $\mathbf{E}$ \\
\hline Initial & $0.011 \mathrm{aA}$ & $0.006 \mathrm{aA}$ & $5.94 \mathrm{bB}$ & $8.54 \mathrm{cA}$ & $1.96 \mathrm{aA}$ & $1.96 \mathrm{aA}$ \\
\hline Juvenile & $0.011 \mathrm{aA}$ & $0.007 \mathrm{aA}$ & $14.81 \mathrm{aA}$ & $11.97 \mathrm{bcB}$ & $1.97 \mathrm{aA}$ & $1.97 \mathrm{aA}$ \\
\hline Mature & $0.009 \mathrm{aA}$ & $0.008 \mathrm{aA}$ & 11.38abA & 16.83abA & $1.87 \mathrm{aA}$ & $1.60 \mathrm{bB}$ \\
\hline Senile & $0.009 \mathrm{aA}$ & $0.009 \mathrm{aA}$ & $14.90 \mathrm{aA}$ & $17.40 \mathrm{aA}$ & $2.00 \mathrm{aA}$ & 1.80abA \\
\hline \multirow{3}{*}{ Stages } & \multicolumn{2}{|c|}{$\mathrm{T}$ Value } & \multicolumn{2}{|c|}{ V } & \multicolumn{2}{|c|}{ Total Clay } \\
\hline & \multicolumn{2}{|c|}{$\left(\mathrm{cmol}_{\mathrm{c}} \mathrm{kg}^{-1}\right)$} & \multicolumn{2}{|c|}{$(\%)$} & \multicolumn{2}{|c|}{$\left(\mathrm{g} \mathrm{kg}^{-1}\right)$} \\
\hline & I & $\mathbf{E}$ & I & $\mathbf{E}$ & I & $\mathbf{E}$ \\
\hline Initial & $3.95 \mathrm{aA}$ & 4.40abA & $40.00 \mathrm{abA}$ & $43.20 \mathrm{aA}$ & $285.70 \mathrm{abA}$ & $278.50 \mathrm{bA}$ \\
\hline Juvenile & $4.03 \mathrm{aA}$ & $4.30 \mathrm{aA}$ & $40.55 \mathrm{bA}$ & 38.50abA & 308.81abA & $299.83 b c A$ \\
\hline Mature & $2.99 \mathrm{bA}$ & $3.95 \mathrm{bA}$ & $37.06 \mathrm{aA}$ & 40.94abA & $233.40 \mathrm{bA}$ & $297.90 \mathrm{bA}$ \\
\hline Senile & $4.50 \mathrm{aA}$ & $4.90 \mathrm{aA}$ & $55.35 \mathrm{bA}$ & $44.00 \mathrm{aA}$ & $355.31 \mathrm{aA}$ & $348.80 \mathrm{aA}$ \\
\hline \multirow{3}{*}{ Stages } & Nat & Clay & & & & \\
\hline & & & & & & \\
\hline & I & $\mathbf{E}$ & I & $\mathbf{E}$ & I & $\mathbf{E}$ \\
\hline Initial & $101.90 \mathrm{aA}$ & 75.30abA & $55.44 \mathrm{aA}$ & $67.49 \mathrm{aA}$ & $528.40 \mathrm{aA}$ & $497.60 \mathrm{aA}$ \\
\hline Juvenile & $131.65 \mathrm{aA}$ & $37.00 \mathrm{bB}$ & $59.75 \mathrm{aA}$ & $73.64 \mathrm{aA}$ & $497.80 \mathrm{aA}$ & $500.60 \mathrm{aA}$ \\
\hline Mature & $124.81 \mathrm{aA}$ & $97.20 \mathrm{aA}$ & $68.57 \mathrm{aA}$ & $68.52 \mathrm{aA}$ & $453.70 \mathrm{aA}$ & $445.00 \mathrm{aA}$ \\
\hline Senile & $101.40 \mathrm{aA}$ & $104.25 \mathrm{aA}$ & $52.25 \mathrm{aA}$ & $64.31 \mathrm{aA}$ & $432.50 \mathrm{aA}$ & $493.40 \mathrm{aA}$ \\
\hline & & & & and & & \\
\hline Stages & & & & & & \\
\hline & I & $\mathbf{E}$ & I & $\mathbf{E}$ & I & $\mathbf{E}$ \\
\hline Initial & $116.70 \mathrm{aA}$ & $104.70 \mathrm{aA}$ & $405.50 \mathrm{aA}$ & 392.90abA & $185.90 \mathrm{bA}$ & $202.80 \mathrm{aA}$ \\
\hline Juvenile & $107.30 \mathrm{aA}$ & $124.90 \mathrm{aA}$ & $380.00 \mathrm{abA}$ & $378.00 \mathrm{aA}$ & $197.00 \mathrm{bA}$ & $199.50 \mathrm{aA}$ \\
\hline Mature & $99.69 \mathrm{aA}$ & $101.31 \mathrm{aA}$ & $350.90 \mathrm{abA}$ & $343.70 \mathrm{bA}$ & $190.90 \mathrm{bA}$ & $186.81 \mathrm{aA}$ \\
\hline Senile & $90.05 \mathrm{aA}$ & $104.89 \mathrm{aA}$ & $341.90 \mathrm{bA}$ & 338.60abA & $334.15 \mathrm{aA}$ & $208.70 \mathrm{aA}$ \\
\hline
\end{tabular}

Equal lowercase letters in the column concern evolutionary stages and equal uppercase letters in the row are inner and outer surfaces, and do not differ by the Kruskal-Wallis test at $5 \%$ significance. I: inner face of the gullies; E: outer face of the gullies.

The highest values for $\mathrm{H}+\mathrm{Al}$ and TOC were found in the external face, with differences between the juvenile and mature stages and between the mature and senile stages on both faces; 
the highest values were associated with senile faces. Higher values for these faces and at this stage may be related to the presence of vegetation, regeneration process, and vegetable residues.

Gomide et al. (2011) found a similar pattern as the one described previously in a study on the interior of gullies in the municipality of Lavras in the state of Minas Gerais. They observed a decrease in the organic matter content caused by the removal of vegetation and, consequently, a decrease in fertility.

The $\mathrm{S}$ value differed between the initial and mature stages and between the juvenile and mature stages on the inner face. Differences were also observed between the faces of mature gullies, with the highest value found in the inner face of the senile stage. For the $\mathrm{T}$ value, differences were observed between the initial and mature stages, juvenile and mature stages, and mature and senile stages, with the highest values for both faces of the gully. For V (\%), the highest values presented the same pattern as that observed for the $\mathrm{T}$ value, differing between the juvenile and mature and between the mature and senile stages on the inner face.

Regarding the granulometric fractions of total clay, the highest values were observed in the senile stage. Differences were detected in the inner face, between the mature and senile gullies, and in the outer face, between initial and senile gullies, juvenile and senile gullies, and mature and senile gullies. The higher values of coarse sand, unlike natural clay, were observed in the initial gully, which may be due to the physical barrier formed by the roots preventing the clay fraction from being carried away. Since it is more difficult to remove the coarse sand fraction because of its size, it is carried away later in the process. For this attribute, differences were found between the initial and senile stages on the inner face and between the juvenile and mature stages on the outer face. For the silt fraction, differences were only observed in the inner face, between the initial and senile gullies, juvenile and senile gullies, and mature and senile gullies.

The variables $\mathrm{Ca}^{2+}, \mathrm{Mg}^{2+}, \mathrm{Na}^{+}, \mathrm{TOC}, \mathrm{S}$ value, fine sand, coarse sand, total clay, and natural clay at 10-20 cm depth were not significantly correlated at a cut-off of $5 \%$ in the Pearson test.

Figure 5 shows the PCA results and Table 4 shows the correlations between the chemical and physical attributes of the soil and axes in the 10-20-cm depth, with a significant correlation at a cut-off of $5 \%$ in the Pearson test.

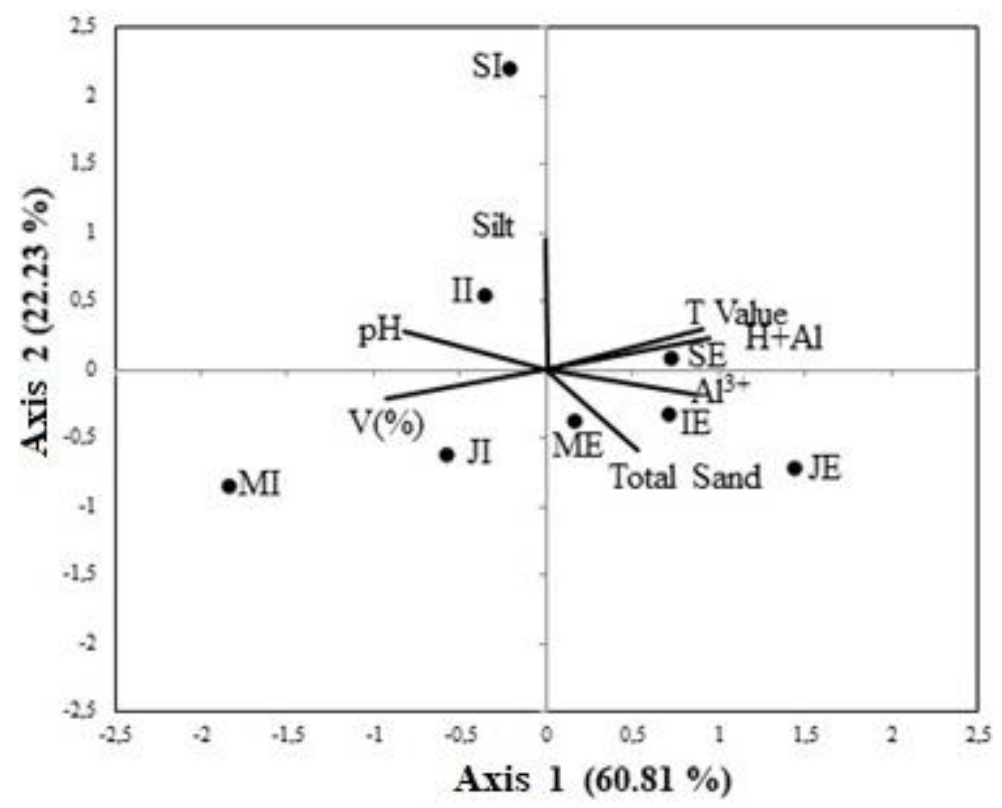

Figure 5. PCA for the chemical and physical variables of the soil in the four evolutionary stages and internal and external faces of the gullies in depth of $10-20 \mathrm{~cm}$. 
Table 4. Values of the correlations between the chemical and physical attributes of the soil and the axes in depth of $10-20 \mathrm{~cm}$ in the analyzed stages.

\begin{tabular}{|c|c|c|c|c|c|}
\hline \multirow[t]{2}{*}{ Axis } & \multicolumn{5}{|c|}{ Chemical Attributes } \\
\hline & pH & $\mathrm{Al}^{3+}$ & $\mathbf{H}+\mathbf{A l}$ & T Value & $\mathrm{V}(\%)$ \\
\hline 1 & -0.81 & 0.85 & 0.95 & 0.90 & -0.93 \\
\hline 2 & 0.27 & -0.17 & 0.24 & 0.30 & -0.20 \\
\hline Axis & \multicolumn{5}{|c|}{ Physicists Attributes } \\
\hline & Total Sand & Silt & & & \\
\hline 1 & 0.53 & -0.002 & & & \\
\hline 2 & -0.58 & 0.96 & & & \\
\hline
\end{tabular}

We verified that the axes 1 and 2 of the PCA separated the chemical and physical attributes of the soil only between the inner and outer faces of their respective evolutionary stages. The sum of the two axes explained $83.04 \%$ of the differences, with axis 1 explaining $60.81 \%$ and axis 2 explaining $22.23 \%$.

For the SE stage, the most associated variables were $\mathrm{H}+\mathrm{Al}(\mathrm{r}=0.95)$ and the $\mathrm{T}$ value $(\mathrm{r}=$ $0.90)$, which showed a negative correlation with axis 1 . The variables most associated with the $\mathrm{IE}, \mathrm{JE}$, and ME stages were $\mathrm{Al}^{3+}(\mathrm{r}=0.85)$, which was positively correlated with axis 1 , and total sand $(\mathrm{r}=-0.58)$, which was negatively correlated with axis 2 . For the JI and MI stages, the most associated variable was $\mathrm{V}(\%)(\mathrm{r}=-0.93)$, which showed a negative correlation with axis 1. For stages II and SI, the variables $\mathrm{pH}(\mathrm{r}=-0.81)$ and silt $(\mathrm{r}=-0.96)$ were more associated and had a negative correlation with axes 1 and 2, respectively.

Analysis of axes 1 and 2 revealed a separation only between the inner faces of the gullies within different evolutionary stages. In general, the outer face of the gullies is more stabilized than the inner face because erosion caused greater changes in its chemical and physical attributes. When conducting a case study to evaluate the role of vegetation in the stabilization of erosive processes by gullies in a degraded landscape in critical areas of Calhoun, Bastola et al. (2018) verified that environments with pre-established vegetation were more stable.

\section{CONCLUSION}

The chemical and physical attributes of soil react differently in different evolutionary stages and (inner and outer) surfaces at depths of $0-10 \mathrm{~cm}$, and only when the faces are at depths of $10-20 \mathrm{~cm}$, respectively.

The stage classified as senile showed the best edaphic conditions for the inner face.

\section{REFERENCES}

ALBUQUERQUE, A. R. da C.; CHATEAUBRIAND, A. D.; PEREIRA, M. C. M.; ROCHA, J. C. F da; NOGUEIRA, L. D.; CARTAXO, E. F. Análise das condições do risco erosivo no entorno do reservatório de Balbina-AM. In: SAFETY, HEALTH AND ENVIRONMENT WORLD CONGRESS, 13., 09-12 Jul. 2013, Vila Real, Portugal. Proceedings[...] Copec, 2013.

ALVARES, C. A.; STAPE, J. L.; SENTElHAS, P. C.; GONÇALVES, J. L. de M.; SPAROVEK, G. Köppen's climate classification map for Brazil. Meteorologische Zeitschrift, v. 22, n. 6 p. 711-728, 2014. https://dx.doi.org/10.1127/09412948/2013/0507 
ARTUR, A. G.; OLIVEIRA, D. P.; COSTA, M. C. G.; ROMERO, R. E.; SILVA, M. V. C.; FERREIRA, T. O. Variabilidade espacial dos atributos químicos do solo, associada ao microrrelevo. Revista Brasileira de Engenharia Agrícola e Ambiental, v. 18, p. 141149, 2014. https://dx.doi.org/10.1590/S1415-43662014000200003

AUMOND, J. J.; MAÇANEIRO, J. P. de. Abordagem sistêmica e aplicação de rugosidades para desencadear propriedades emergentes em restauração de solos degradados. Ciência Florestal, v. 24, p. 759-764, 2014. https://dx.doi.org/10.5902/1980509815737

AYER, J. E. B.; OLIVETTI, D.; MINCATO, R. L.; SILVA, M. L. N. Erosão hídrica em Latossolos Vermelhos distróficos. Pesquisa Agropecuária Tropical, v. 45, p. 180-191, 2015. https://dx.doi.org/10.1590/1983-40632015v4531197

BASTOLA, S.; DIALYNAS, Y. G.; BRAS, R. L.; NOTO, L. V.; ISTANBULLUOGLU, E. The role of vegetation on gully erosion stabilization at a severely degraded landscape: a case study from Calhoun experimental critical zone observatory. Geomorphology, v. 308, p. 25-39, 2018. https://dx.doi.org/10.1016/j.geomorph.2017.12.032

BOGUNOVIC, I.; PEREIRA, P.; KISIC, I.; SAJKO, K.; SRAKA, M. Tillage management impacts on soil compaction, erosion and crop yield in Stagnosols (Croatia). Catena, v. 160, p. 376-84, 2018. https://dx.doi.org/10.1016/j.catena.2017.10.009

CHEROBIN, S. F. Estimativa de erosão e sua relação com os diferentes mecanismos erosivos atuantes: estudo da voçoroca Vila Alegre. 2012. 115f. Dissertação (Mestrado em Engenharia Ambiental) - Universidade Federal de Ouro Preto, Ouro Preto, 2012.

DENG, Y.; XIA, D.; CAI, C.; DING, S. Effects of land uses on soil physic-chemical properties and erodibility in collapsing-gully alluvial fan of Anxi County, China. Journal of Integrative Agriculture, v. 15, p. 1863-1873, 2016. https://dx.doi.org/10.1016/s20953119(15)61223-0

DOBEK, K.; DEMCZUK, P.; RODZIK, J.; HOLUB, B. Types of gullies and conditions of their development in silvicultural loess catchment (Szczebrzeszyn Roztocze region, Poland). Landform Analysis, v. 17, p. 39-42, 2011.

FERREIRA, E. de M.; ANDRAUS, M. de P.; CARDOSO, A. A.; COSTA, L. F. dos S.; LÔBO, L. M.; LEANDRO, W. M. Degraded areas recovery, green manure and water quality. Revista Monografias Ambientais, v. 15, p. 228-246, 2016. https://dx.doi.org/10.5902/22361308

GAIA-GOMES, J. H. Caracterização morfométrica da sub-bacia do ribeirão Cachimbal, RJ e atributos edáficos condicionantes no processo erosivo em pedoformas côncava e convexa. 2017. 109f. Dissertação (Mestrado em Engenharia Agrícola e Ambiental) Universidade Federal Rural do Rio de Janeiro, Seropédica, 2017.

GOMIDE, P. H. O.; SILVA, M. L. N.; SOARES, C. R. F. S. Atributos físicos, químicos e biológicos do solo em ambientes de voçorocas no município de Lavras - MG. Revista Brasileira de Ciência do Solo, v. 35, p. 567-577, 2011. https://dx.doi.org/10.1590/s0100-06832011000200026

LAURANCE, W. F.; SAYER, J.; CASSMAN, K. G. Agricultural expansion and its impacts on tropical nature. Trends in Ecology \& Evolution, v. 29, p. 107-116, 2014. https://dx.doi.org/10.1016/j.tree.2013.12.001 
LIMA, J. S. S.; SOUZA, G. S. de, SILVA, S. de A. Distribuição espacial da matéria orgânica, grau de floculação e argila dispersa em água em área de vegetação natural em regeneração e pastagem. Revista Árvore, v. 37, p. 539-546, 2013. https://dx.doi.org/10.1590/s010067622013000300017

MACHADO, R. L.; RESENDE, A. S. de; CAMPELLO, E. F. C.; OLIVEIRA, J. Á.; FRANCO, A. A. Soil and nutrient losses in erosion gullies at different degrees of restoration. Revista Brasileira de Ciência do Solo, v. 34, p. 945-954, 2010. https://dx.doi.org/10.1590/s0100-06832010000300036

MENEZES, C. E. G.; PEREIRA, M. G.; CORREIA, M. E. F.; ANJOS, L. H. C.; PAULA, R. R.; SOUZA, M. E. de. Litter contribution and decomposition and root biomass production in forests at different successional stages in Pinheiral, RJ. Ciência Florestal, v. 20, p. 439-452, 2010. https://dx.doi.org/10.5902/198050982059

SANTOS, R. D.; LEMOS, R. C. de, SANTOS, H. G. dos.; KER, J. C.; ANJOS, L. H. C. dos; SHIMIZU, S. H. Manual de descrição e coleta de solo no campo. 5. ed. Viçosa: Universidade Federal de Viçosa, 2015. 343p.

SANTOS, G. L. dos; PEREIRA, M. G.; LIMA, S. S. de; CEDDIA, M. B.; MENDONÇA, V. M. M.; DELGADO, R. C. Landform curvature and its effect on the spatial variability of soil attributes, Pinheiral-RJ/BR. Cerne, v. 22, p. 431-438, 2016. https://dx.doi.org/10.1590/01047760201622042184

SANTOS, G. L. dos; PEREIRA, M. G.; DELGADO, R. C.; MORAES, L. F. D. de. Padrões da regeneração natural na região de Mar de Morros, Pinheiral-RJ. Floresta e Ambiente, v. 24, p. 1-11, 2017. https://dx.doi.org/10.1590/2179-8087.008115

SCHJONNING, P.; MCBRIDE, R. A.; KELLER, T.; OBOUR, P. B. Predicting soil particle density from clay and soil organic matter contents. Geoderma, v. 296, p. 83-87, 2017. https://dx.doi.org/10.1016/j.geoderma.2016.10.020

SOUSA NETO, E. L. de; ANDRIOLI, I.; ALMEIDA, R. G.; MACEDo, M. C. M.; LAL, R. Physical quality of an Oxisol under an integrated crop-livestock-forest system in the Brazilian Cerrado. Revista Brasileira de Ciência do Solo, v. 38, p.608-618, 2014. https://dx.doi.org/10.1590/S0100-06832014000200025

TEIXEIRA, P. C.; DONAGEMMA, G. K.; FOnTANA, A.; TEIXEIRA, W. G. Manual de Métodos de Análise de Solo. 3. ed. Rio de Janeiro: Embrapa Solos, 2017. 264 p.

YEOMANS, J. C.; BREMNER, J. M. A rapid and precise method for routine determination of organic carbon in soil. Communications in Soil Science and Plant Analysis, v. 19, p. 1467-1476, 1988. https://dx.doi.org/10.1080/00103628809368027 